institutions create their own constituencies of support, among both staff and patients. They are visible, concentrated, and organised interest groups. They can bring out their supporters. In contrast, the beneficiaries of change may be diffuse, ill organised, and often difficult to identify. ${ }^{5}$ The argument can be simply illustrated. Any attempt to shift resources from curative to preventive services inevitably means antagonising those who either provide or benefit from curative services in order to benefit future generations: the future has no constituency that can be mobilised as a counterweight to existing interests threatened by change. In this sense there is a built in asymmetry or imbalance that loads the dice against reformers.

There is a further asymmetry special to the NHS. This is the asymmetry between London and the rest of the country. The concentration of teaching hospitals in London and the resultant disproportionate share of resources that has gone to the capital's health services have been a matter of concern throughout this century. ${ }^{6}$ The NHS reforms have, in this as in other respects, simply given new visibility - and added edge - to an old issue. This stems from the division between purchasers and providers (whether or not they are trusts). It is for the purchasers to buy the services required by their populations; it is for the providers to provide them to the right standard, at the right price. In other words, the emphasis has switched from the maintenance of institutions to the provision of services. Hence the dilemma of London teaching hospitals, and others. The logic of the new system is that if they can provide the appropriate services at the appropriate price they will survive. If not, they may have to adjust the scale and scope of their activities: a process that, clearly, has already begun-so setting off the latest political explosion.

It is precisely the distinction between services and institutions that may, furthermore, provide the key for any attempt to disentangle the political and substantive impact of the NHS reforms. Institutions matter in the new system, it may be argued, only to the extent that they are required to provide specific services, although health authorities would obviously be very unwise to ignore the effects of damaged morale on the provision of those services. It follows, then, that the real test of what is happening in the NHS now must surely be the way in which the purchasing authorities are commissioning services and monitoring their delivery. And if this is so, attention should shift to the purchasing agreements and contracts that have been issued by the health authorities. As far as services to patients are concerned, these are the crucial documents rather than the business plans of trusts (though that should be no reason for frustrating public accountability by making such trust documents inaccessible to parliamentary scrutiny).

It is the purchasing agreements and contracts that should answer the question of what is being provided to whom and provide information about changes in levels of service, access, availability, and standards over time. For it is these that should specify the quantity and quality of services being delivered to a particular population. The first batch of agreements and contracts, drawn up in a rush and designed to minimise turbulence, probably fail to specify precise enough benchmarks against which to measure change - whether for better or worse. But if we are to start making sense of what the reforms are doing to the NHS, cutting through the political noise, then clearly there must be an intensive and urgent push in this direction. If the government wants its record to be judged at the next general election not by the input of resources into the NHS but by the output of services it is clearly essential to have more information about the adequacy, quality, and scope of what is being provided by individual health authorities. In the absence of such information it is impossible to come to any conclusive judgment about either the total budget or the significance of cutbacks in individual hospitals.

Professor of Social Policy,

RUDOLF KLEIN

Centre for the Analysis of Social Policy,

School of Social Sciences,

University of Bath BA2 7AY

Groves T. Guy's and Lewisham Trust "sorts itself out." BMF 1991;302:1039. (4 May.)

2 Enthoven AC. Reflections on the management of the National Health Service. London: Nuffield Provincial Hospitals Trust, 1985.

3 Klein R. The politics of the NHS. London: Longmans, 1983.

4 Secretaries of State for Health, Wales, Northern Ireland, and Scotland. Working for patients. London: HMSO, 1989. (Cmnd 555.

Marmor TR. Political analysis and American medical care. Cambridge: Cambridge University Press, 1983.

Rivett G. The development of the London hospital system, 1823-1982. London: King Edward's Hospital Fund for London, 1986

\title{
Escaping insulin dependent diabetes
}

\section{Characteristic immunological changes don't invariably lead to disease}

Insulin dependent diabetes mellitus is caused by an immunologically mediated destruction of the $\beta$ cells in the islets of Langerhans. The disease process is associated with immune changes in the peripheral blood and includes the production of autoantibodies to islet cells and to insulin and increased concentrations of activated $\mathrm{T}$ lymphocytes expressing the HLA-DR antigen.' Genetic susceptibility to insulin dependent diabetes is mediated predominantly by HLA genes. ${ }^{2}$ The disease seems to result from an environmental event, possibly exposure to either a virus or a toxin, over a brief period in early childhood. ${ }^{3}$ After this event an antigen, either an islet autoantigen or a viral antigen, is presented to a $\mathrm{T}$ cell receptor by the HLA molecule. The resultant immune response leads to the destruction of most of the insulin secreting cells and finally to insulin dependent diabetes.

We used to think that this was a rapid process. But is it? Twenty five years ago Lister and colleagues showed that even in children clinical symptoms had been present for a few months before the diagnosis of insulin dependent diabetes. ${ }^{4} \mathrm{It}$ is now apparent that clinical, immunological, and metabolic changes may start years before the onset of the disease. This prediabetic period may be characterised by growth delay, ${ }^{5}$ the presence of autoantibodies to islet cell proteins including insulin $^{6}$ and a $64 \mathrm{kDa}$ protein (possibly glutamic acid decarboxylase), ${ }^{7}$ activation of T lymphocytes, ${ }^{8}$ impaired glucose tolerance, ${ }^{9}$ a decreased insulin response to intravenous glucose,${ }^{10}$ and increased fasting proinsulin concentrations. ${ }^{11}$

We have assumed that once started these changes inevitably led to diabetes, but now this also seems doubtful. Increased concentrations of activated $\mathrm{T}$ lymphocytes and autoantibodies to both islet cells and insulin have been detected in nondiabetic twins or siblings of diabetic patients, who were unlikely to develop diabetes. ${ }^{612} 13$ Furthermore, islet cell antibodies can disappear without the child developing dia- 
betes. ${ }^{12-16}$ The titre of islet cell antibodies may be important in determining the outcome. In two large studies of relatives of diabetic patients followed for up to eight years 21 of 38 of those with high titres of islet cell antibodies ( $>40$ JDF units) developed insulin dependent diabetes while of those with low titres of antibodies ( $<20 \mathrm{JDF}$ units) only four of 36 became diabetic. $^{1718}$

These immune changes may be accompanied by altered function of islet cells. Impaired glucose tolerance was observed in five of 41 identical twins of diabetic patients who later regained normal glucose tolerance. ${ }^{9} \mathrm{~A}$ decreased insulin response to intravenous glucose that did not deteriorate over five years has also been described in 17 of 20 relatives of diabetic patients. ${ }^{19}$ Finally, increased peripheral blood concentrations of proinsulin, the precursor of insulin, have been found in twins and siblings of diabetic patients many years after the diagnosis of the index case, when they themselves were unlikely to develop insulin dependent diabetes. ${ }^{112021}$ Thus immunological and metabolic changes may be present that do not progress to diabetes.

Confidently distinguishing changes that predict diabetes from those that may remit will be vital if we are to use immunosuppression or other treatment in those at risk of developing the disease. How do people who develop diabetes differ from those who do not? A critical role is likely to be played by the HLA molecule, the antigen, and the $T$ cell receptor - which together are central to the development of an immune response. The structure of the HLA molecules, as coded by genes in the HLA-DQ and DR regions, is important. ${ }^{2}$ These HLA molecules are formed from an $\alpha$ chain and a $\beta$ chain of amino acids, which probably form a "pocket" in which the antigen sits. The nature of the amino acids lining this pocket or peptide binding site could determine the ability of antigen to bind and, by implication, to be presented to the peptide receptor on $T$ lymphocytes. It is becoming apparent that HLA mediated susceptibility cannot be ascribed to any one amino acid. Rather it is the overall structure of each HLADQ and some HLA-DR molecules that confers resistance or susceptibility to the disease. ${ }^{22}$ Most identical twins, who have the same HLA genes, are, however, discordant for insulin dependent diabetes, so factors other than genetic susceptibility must be important. The antigen is also important - antibodies to the islet cell better predict insulin dependent diabetes than do antibodies to insulin, ${ }^{6}$ and high titres are more predictive than low titres of islet cell antibodies. ${ }^{17}{ }^{18}$ Little is known of the third component of the molecular complex, the $\mathrm{T}$ cell receptor.

We have known for some years that immunologically mediated changes in organ specific diseases such as thyroiditis may occur without necessarily leading to destruction of the target cells. It now looks as if the process associated with insulin dependent diabetes also encompasses immune and metabolic changes that may progress, persist, or remit. If we could understand what determines the outcome then we might learn how to prevent insulin dependent diabetes. That may still be a distant prospect but it is an enticing one.

Wellcome Trust Senior Fellow and

R D G LESLIE

Honorary Consultant Physician,

Westminster Hospital,

London SW1P 2AR

Formerly Consultant Physician,

D A PYKE

King's College Hospital,

London SE5 9RS

1 Leslie RDG, Lazarus NR, Vergani D. Aetiology of insulin dependent diabetes. Br Med Bull 1989;45:58-72

2 Todd JA, Acha-Orbea H, Bell JI, et al. A molecular basis for MHC class II-associated autoimmunity. Science 1988;240:1003-9.

3 Olmos P, A'Hern R, Heaton DA, et al. The significance of the concordance rate for type 1 (insulindependent) diabetes in identical twins. Diabetologia 1988;31:747-50.

4 Hamilton DV, Mundia SS, Lister J. Mode of presentation of juvenile diabetes. BMF 1976;ii:211-2.

5 Hoskins PJ, Leslie RDG, Pyke DA. Height at diagnosis of diabetes in children: a study in identical twins. BMF 1985;290:278-80.

6 Ziegler AG, Zeigler R, Vardi P, et al. Life-table analysis of progression to diabetes of anti-insulin autoantibody-positive relatives of individuals with type 1 diabetes. Diabetes 1989;38:1320-5.

7 Baekkeskov S, Aanstoot $\mathrm{H}-\mathrm{J}$, Christgau S, et al. Identification of the $64 \mathrm{~K}$ autoantigen in insulin dependent diabetes as the GABA-synthesizing enzyme glutamic acid decarboxylase. Nature 1990;347:151-6.

8 Alviggi L, Johnston C, Hoskins PJ, et al. Pathogenesis of insulin-dependent diabetes: a role for activated T lymphocytes. Lancet 1984; ii:4-6.

9 Beer SF, Heaton DA, Alberti KGMM, Pyke DA, Leslie RDG. Impaired glucose tolerance precedes but does not predict insulin dependent diabetes mellitus: a study of identical twins. Diabetologia 1990;33:497-502.

10 Srikanta S, Ganda OP, Soeldner JS, Eisenbarth GS. First degree relatives of patients with type 1 diabetes mellitus; islet cell antibodies and abnormal insulin secretion. $N$ Engl $\mathcal{F}$ Med 1985;313:461-4.

11 Heaton D, Millward BA, Gray IP, et al. Increased proinsulin levels as an early indicator of beta cell dysfunction in non-diabetic twins of type 1 (insulin-dependent) diabetic patients. Diabetologia

12 Millward $\mathrm{BA}$, Alviggi L, Hoskins PJ, et al. Immune changes associated with insulin dependen diabetes may remit without causing the disease: a study in identical twins. BMf 1986;292:793-6. diabetes may remit without causing the disease: a study in identical twins. BMF 1986;292:793-6.
Johnston C, Millward BA, Hoskins P, Leslie RDG, Bottazzo GF. Islet-cell antibodies as predictors of the later development of type 1 (insulin-dependent) diabetes. Diabetologia 1989;32:382-6.

14 Karjalainen JK. Islet cell antibodies as predictive markers for IDDM in children with high background incidence of disease. Diabetes 1990;39:1144-50.

15 Notsu K, Oka N, Note S, et al. Islet cell antibodies in the Japanese population and subjects with type 1 (insulin-dependent) diabetes. Diabetologia 1985;28:660-2.

16 Landin-Olsson M, Karlsson A, Dahlquist G, Blom L, Lernmark A, Sundkvist G. Islet cell and other organ specific autoantibodies in all children developing type 1 (insulin-dependent) diabetes. Diabetologia 1989;32:387-95.

17 Riley WJ, Maclaren NK, Krischer J, et al. A prospective study of the development of diabetes in relatives of patients with insulin-dependent diabetes. $N$ Engl f Med 1990;323:1167-72.

18 Bonifacio E, Bingley P, Shatock M, et al. Quantification of islet cell antibodies and prediction of insulin-dependent diabetes. Lancet 1990;335:147-9.

$19 \mathrm{McCulloch}$ DK, Klaff LJ, Kahn SE, et al. Nonprogression of subclinical B-cell dysfunction among first-degree relatives of IDDM patients. Diabetes 1990;39:549-55.

20 Heaton DA, Millward BA, Gray P, et al. Evidence of $\beta$-cell dysfunction which does not lead on to diabetes: a study of identical twins of insulin dependent diabetics. BMF 1987;294:145-6.

21 Hartling SG, Lindgren F, Dahlqvist G, Persson B, Binder C. Elevated proinsulin in healthy siblings of IDDM patients independent of HLA identity. Diabetes 1989;38:1271-4

22 Khalil I, d'Auriol L, Gobet M, et al. A combination of HLA DQ $\beta$ Asp57-negative and HLA DQalpha Arg52 confers susceptibility to insulin dependent diabetes mellitus. $\mathcal{F}$ Clin Invest 1989;85:1315-9.

\section{Correction}

\section{New developments in renin and angiotensin}

An editorial error occurred in this editorial by N J Samani (27 April, p 481). In the fourth paragraph, the sixth sentence should have included mention of the adrenals; it should read, "On the other hand, concentrations of renin messenger RNA and renin activity were both found to be appreciably increased in the adrenals." 